九州大学学術情報リポジトリ

Kyushu University Institutional Repository

\title{
Action of 5-Methyl-3,4-dihydroxytetrone on Deoxyribonucleic Acid
}

Omura, Hirohisa

Food Chemistry Institute, Faculty of Agriculture, Kyushu University

Fukumoto, Yuj i

Food Chemistry Institute, Faculty of Agriculture, Kyushu University

Tomita, Yoshifumi

Food Chemistry Institute, Faculty of Agriculture, Kyushu University

Shinohara, Kazuki

Food Chemistry Institute, Faculty of Agriculture, Kyushu University

https://doi.org/10.5109/22876

出版情報 : 九州大学大学院農学研究院紀要. 19 (2/3)，pp. 139-148，1975-03. Kyushu University バージョン：

権利関係 : 
J. Fac. Agr., Kyushu Univ., 19, 139-148 (1975)

\title{
Action of 5-Methyl-3,4-dihydroxytetrone on Deoxyribonucleic Acid*
}

\author{
Hirohisa Omura, Yuji Fukumoto**, Yoshifumi Tomita \\ and Kazuki Shinohara
}

Food Chemistry Institute, Faculty of Agriculture, Kyushu University, Fukuoka

(Received December 25, 1974)

\begin{abstract}
In connection with antitumoric potentiality of 5-methyl-3,4-dihydroxytetrone (MDT), its stability in the presence of $\mathrm{Cu}^{2+}$ and action on DNA were investigated. It was observed that MDT is relatively stable in acid medium even in the presence of $\mathrm{Cu}^{2+}$, while it is rapidly decomposed in alkali.

Viscosity of DNA solution was lowered a little by MDT. However, $\mathrm{Cu}^{2+}$ accelerated exceedingly the lowering, whereas few promotion was brought about by $\mathrm{Fe}^{2+}$ or $\mathrm{Fe}^{3+}$. By the sucrose density gradient centrifugation, disintegration of DNA with MDT was disclosed. Double and single strand cissions were caused depending on the concentration of MDT. In this case too, breakage of DNA was enhanced with $\mathrm{Cu}^{2+}$. Apyrimidinic and apurinic acids were also similarly degraded by the action of MDT.
\end{abstract}

\section{INTRODUCTION}

Reductones have been recently paid a remarkable attention as the important main intermediate in variation of color, odor or nutritive value during cooking, processing and storage of food. Furthermore, they are expected to have some physiological function due to their peculiar properties such as significant reducing ability, since many physiologically important substances are included in the group of reductone. Ascorbic acid (AsA), which is a typical reductone contained in food, is vitamin $\mathrm{C}$ and employed often in food manufacture too. Catecholamines such as dopa, dopamine, adrenaline and noradrenaline, a sort of aromatic reductone, are successively synthesized from phcnylalanine or tyrosine by a metabolic chain in vivo. Dopa and dopamine participate in food browning and are known to be effective against Parkinson's disease. A neurohormone, noradrenaline, is secreted by the action current induced when nerve is stimulated, and transmits an impulse to receptor cells. On the other hand, an adrenomedullary hormone, adrenaline, is concerned in control of blood sugar level and blood pressure. Boyland and Watson (1956) reported that 3-hydroxykynurenine and 3hydroxyanthranylic acid, intermediates in tryptophan metabolism, induce bladder carcinoma. Both compounds should be regarded as enaminol reductone rather than aromatic amine in carcinogenic process. In addition, it was confirmed in

* Study on the physiological function of reductones. Part XI.

** Present address: Teijin Co., Ltd. 
our institute that AsA and its oxidized products (Nakamura and Yamafuji, 1968 ; Yamafuji et al., 1971) - dehydroascorbic acid (DAsA) and 2,3-diketogulonic acid (DKG) - and catecholamines (Murakami and Yamafuji, 1969, 1970 ; Yamafuji et al., 1970) repress the growth of sarcoma-180. Yamafuji (1970) demonstrated that one of the primary starting processes for cellular anomalization including carcinogenesis, carcinostasis, mutagenesis and virogenesis must be the suitable breaks of chromosomal DNA. The cleavage of DNA with reductones cited above was confirmed and suggested that the functional group of these reductones must be a "reductone structure" such as enediol, its oxidized form or enaminol in molecule (Yamafuji et al., 1970, 1971a, 1972). From this point of view, we have surveyed the antitumoric potentiality among the reductones. Thus, it was found that, in addition to AsA,DAsA and DKG, erythorbic acid, dehydroerythorbic acid and ascorbyl palmitate have more or less the antitumoric potetntiality as well as the DNA-breaking ability, but DAsA loses the activities when it is combined with o-phenylenediamine to block its "reductone structure" (Omura et al., 1974). AsA is easily decomposed and 5-methyl-3,4-dihydrotetrone (MDT) is formed as one of the products. MDT also contains enediol group and alternatively named as reductone A. Since the antitumoric potentiality of MDT was established in relation to the AsA-derivatives (Tomita et al., 1974), action of MDT on DNA was examined.

\section{MATERIALS AND METHODS}

\section{5-Methyl-3,4-dihydroxytetrone (M D T)}

MDT was prepared by decomposition of DAsA in $1 \mathrm{~N} \mathrm{H}_{2} \mathrm{SO}_{4}$ according to Euler and Hasselquist (1955), as described in the preceding paper (Tomita et al., 1974).

\section{Deoxyribonucleic acid (DNA)}

a) Calf thymus DNA Calf thymus DNA was prepared by the routine SDS-phenol method from fresh calf thymus excised soon after slaughter.

b) Sarcoma-I80 DNA Because it is difficult to prepare intact high molecular DNA from sarcoma-180 by the same method as for calf thymus DNA, the preparation of sarcoma-180 DNA was carried out as follows mainly according to Saito and Miura (1963). Ascites were harvested one week after implantation with tumor cells into abdominal cavity of female ddN mice. About $50 \mathrm{ml}$ ascites were obtained from 10 mice. Tumor cells were collected by centrifugation at 5,000 r. p. m. for 10 minutes and washed twice with $1 x$ SSC $(0.15 \mathrm{M}$ sodium chloride $+0.015 \mathrm{M}$ sodium citrate) and then further twice with $0.1 x \mathrm{SSC}$ in cold. Thus, white tumor cells were available due to easy hemolysis by this procedure. The cells were suspended in $0.1 \mathrm{M}$ Tris buffer ( $\mathrm{pH}$ 9) containing $1 \%$ SDS under gradual addition of the buffer with stirring. At room temperature, the cell suspension was homogenized and kept for 20 to 30 minutes to cause cytolysis. The cell solution was then mixed with $100 \mathrm{ml}$ of phenol saturated with water and the mixture was gently stirred at $0^{\circ} \mathrm{C}$ for 20 minutes. After centrifugation at 10,000 r. p. m. for 20 minutes to remove cell debri, 0.1 volume of $3 \mathrm{M}$ sodium acetate-0.001 M EDTA solution was added into the supernatant. Nucleic acids 
were then precipitated by gentle mixing the solution with an equal volume of isopropanol. The fibrous precipitate was collected on a glass rod, washed stepwise with 70 to $90 \%$ ethyl alcohol. After the precipitate was completely dissolved in $0.1 \mathrm{x}$ SSC, 0.1 volume of $10 \mathrm{x}$ SSC was added. EDTA was then dissolved to a final concentration of $1 \mathrm{mM}$ and RNase $A$ and RNase $T_{1}$ were added. The solution was incubated at $37^{\circ} \mathrm{C}$ for 30 minutes to degrade contaminating RNA and cooled. The reaction mixture was mixed with equal volume of phenol, gently stirred at $0^{\circ} \mathrm{C}$ for 10 minutes and centrifuged at 10,000 r. p. m. for 20 minutes. Again, $\mathbf{0 . 1}$ volume of sodium acetate-EDTA was added in the supernatant. The fibrous DNA preparation was obtained by isopropanol treatment and ethanol washing as above.

\section{Apyrimidinic acid (ApyA) and Apurinic acid (ApuA)}

ApyA was principally prepared by Takemura's method as follows except that the hydrazine treatment was elongated. Into bovine spleen DNA (600 mg), which had been prepared by SDS-method and dried in vacuo at $60^{\circ} \mathbf{C}$ for 5 hours over sulfuric acid, hydrazine $(8.4 \mathrm{ml})$ purified by distillation was added and incubated at $60^{\circ} \mathrm{C}$ for 2 hours to eliminate pyrimidine bases exclusively. After cooling the reaction mixture, ApyA was precipitated by adding 5 volumes of ethanol. The precipitate was washed with ether and dissolved in water. The solution was dialyzed against running tap water and then deionized water, and lyophilized.

The preparation of ApuA was carried out as described by Tamm et al. (1952). Bovine spleen DNA (400 mg) was dissolved in deionized water $(85 \mathrm{ml})$ and mixed with $0.1 \mathrm{~N} \mathrm{HCl}(25 \mathrm{ml})$. The mixture was dialyzed successively against $\mathrm{HCl}$ aqueous solution ( $\mathrm{pH} 1.8$ ) at $37^{\circ} \mathrm{C}$ for 26 hours, $0.2 \mathrm{M}$ borate buffer ( $\mathrm{pH} 7.3$ ) at $4^{\circ} \mathrm{C}$ for 22 hours, running tap water at $4^{\circ} \mathrm{C}$ for 24 hours and finally distilled water at $4^{\circ} \mathrm{C}$ for 24 hours, and lyophilized.

Complete elimination of pyrimidine bases in ApyA and that of purine bases in ApuA were established by the paper chromatography.

\section{Viscosity measurement}

Time course of viscosity of the mixture containing $100 \mu \mathrm{g} / \mathrm{ml}$ DNA, $0.1 \mathrm{M}$ phosphate buffer (pH 7.0), $1 \mathrm{mM}$ MDT and $0.2 \mathrm{mMCuSO}_{4}$ was measured in an Ostwald's viscometer at $37^{\circ} \mathrm{C}$.

\section{5 . Sucrose density gradient centrifugation}

The reaction mixture composed of $0.4 \mathrm{ml}$ of DNA solution $(250 \mu \mathrm{g} / \mathrm{ml}), \mathrm{I} \mathrm{ml}$ of $0.1 \mathrm{M}$ phosphate buffer, $0.1 \mathrm{ml}$ of MDT solution and distilled water to be $2 \mathrm{ml}$ of the total volume, The mixture was incubated at $37^{\circ} \mathrm{C}$ for 2 hours in the case of sarcoma-180 DNA or for 4 hours when calf thymus DNA was employed. The solution was dialyzed against $1 \times \mathrm{xSC}$ at $4^{\circ} \mathrm{C}$, and $0.2 \mathrm{ml}$ aliquot was laid on the top of the sucrose gradient in a tube (5\% to $20 \%$ sucrose, $\mathrm{pH} 8$ or 12.5). After centrifugation at $\mathbf{3 0 , 0 0 0}$ r. p. m. for 4 hours, the solution was fractionated from the bottom of the tube at 4 drops each. To each fraction was added $1 \mathrm{ml}$ of deionized water and the absorbancy at $260 \mathrm{~nm}$ was estimated with a microcell of a Hitachi spectrophotometer.

The molecular weight of DNA fractions formed was roughly calculated from 
the centrifuging pattern according to the equations described by Studier (1965). In the case of the neutral density gradient centrifugation of natural DNA, the sedimentation coefficient is given by

$$
\mathrm{S}=0.0822 \mathrm{M}^{0.346} ; \mathrm{S}=\frac{6.45 \times 10^{10} \mathrm{D}}{\omega t}
$$

where $\mathrm{S}=$ sedimentation coefficient (Svedberg unit)

$\mathrm{M}=$ molecular weight

$\mathrm{D}=$ distance from meniscus to DNA band $(\mathrm{cm})$

$\omega=$ revolution number (r. p. m.)

$t=$ centrifugation time (hour)

In the case of the alkaline centrifugation of natural DNA, S is given by

$$
\mathrm{S}=0.0528 \mathrm{MO} .400 ; \mathrm{S}=\frac{7.1 \times 10^{10} \mathrm{D}}{\omega t} \text {. }
$$

\section{Gel filtration}

Into $1.5 \mathrm{ml}$ of Apy A or ApuA solution $(1 \mathrm{mg} / \mathrm{ml})$ dissolved in $0.1 \mathrm{M}$ phosphate buffer (pH7), $1 \mathrm{ml}$ of $0.15 \mathrm{M} \mathrm{MDT}$ and $0.5 \mathrm{ml}$ of $6 \mathrm{mMCuSO}_{4}$ were added. The mixture was incubated at $37^{\circ} \mathrm{C}$ for 24 hours, dialyzed against deionized water at $5^{\circ} \mathrm{C}$ overnight, and applied to a $100 \times 1.6 \mathrm{~cm}$ column of Sephadex G-50 (medium). ApyA and ApuA were eluted with deionized water at a rate of $5 \mathrm{ml} / 10 \mathrm{~min}$ utes. The absorption of each fraction containing $5 \mathrm{ml}$ was estimated at $256 \mathrm{~nm}$ for ApyA and at $269 \mathrm{~nm}$ for ApuA.

\section{RESULTS}

\section{Stalility of MDT in the presence of $\mathrm{Cu}^{2+}$}

Reductones are relatively unstable, especially in the presence of $\mathrm{Cu}^{2+}$. Therefore, when the action of MDT on DNA was examined with $\mathrm{Cu}^{2+}$, it seems necessary to follow the change of MDT concentration during the reaction, since it brings about the variation of the ability of MDT. The stability of MDT was estimated by determining its absorption spectra at different pH. MDT and $\mathrm{CuSO}_{4}$ were dissolved in $\mathrm{HCl}-\mathrm{KCl}$ buffer $(\mathrm{pH} 2)$, acetate buffer (pH5.6), phosphate buffer ( $\mathrm{pH} 7.0$ ) or $\mathrm{NaOH}-\mathrm{KCl}$ buffer ( $\mathrm{pH} 12$ ) to give a final concentration of 50 $\mu \mathrm{M}$ and $5 \mu \mathrm{M}$ respectively. These solutions were kept at $25^{\circ} \mathbf{C}$ for different times and the absorption spectra were measured by a Shimadzu multipurpose recording spectrophotometer.

As shown in Fig. 1, MDT is stable at acid $\mathrm{pH}$ even in the presence of $\mathrm{Cu}^{2+}$, while above the neutral region the spectral change occurs rapidly. The absorption maximum at $265 \mathrm{~nm}$ disappears within 6 minutes at $\mathrm{pH} 5.6,2$ minutes at pH 7 or 1 minute at $\mathrm{pH} 12$. Although these vanishing time of the maximum absorption may depend on the concentration of MDT, the tendency of the absorption change should be kept in mind.

\section{Change of viscosity of DNA Solution}

The change of the viscosity of DNA solution treated with MDT is shown in Fig. 2. Only $1 \mathrm{mM}$ MDT does not bring about the lowering of the viscosity. 


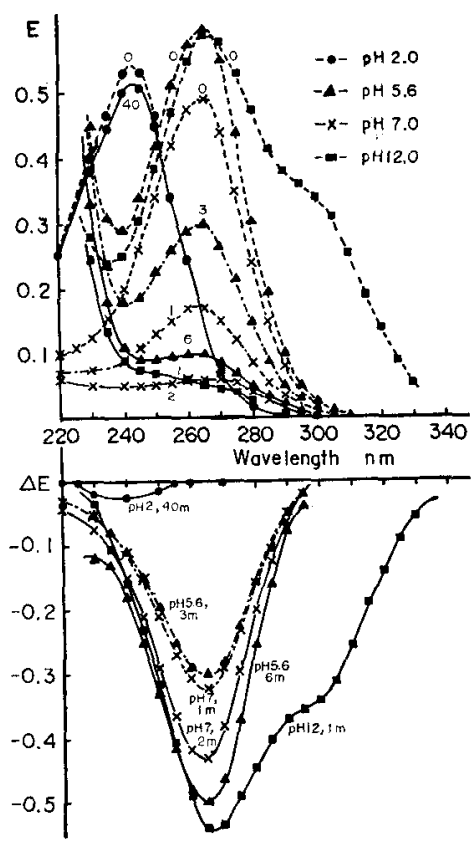

Fig. 1. Stability of MDT in the presence of $\mathrm{Cu}^{2+}$ at different $\mathrm{pH}$.

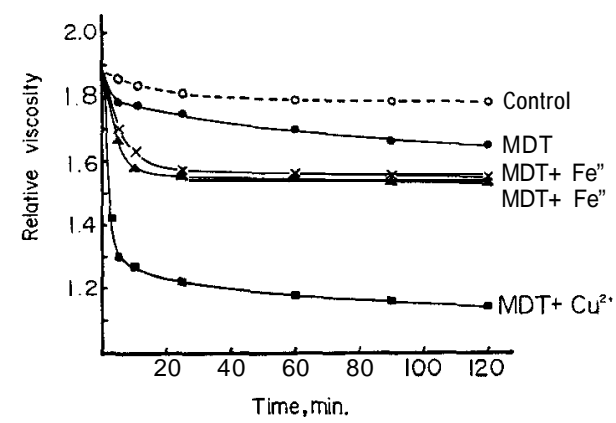

Fig. 2. Effect of MDT on the viscosity of DNA solution.

However, the addition of small amount of $\mathrm{Cu}^{2+}$ causes the lowering rapidly, while $\mathrm{Cu}^{2+}$ alone possesses no lowering activity. The viscosity was lowered to some extent with MDT and $\mathrm{Fe}^{2+}$ or $\mathrm{Fe}^{3+}$, but their effect was weaker than that of $\mathrm{Cu}^{2+}$. These phenomena resemble those with other reductones such as AsA and its derivatives.

\section{Sucrose density gradient centrifugation}

As stated often, the lowering of the viscosity is not sufficient to indicate the depolymerization of DNA. Therefore, DNA was treated with MDT, dialyzed to remove the reagents and some products of lower molecular weight in cold 
and analyzed by the sucrose density gradient centrifugation. In relation to the antitumoric potentiality of MDT, sarcoma-180 DNA was employed in the study. Furthermore, calf thymus DNA was also treated for comparing the ability of MDT with that of other nucleic acid breaking reagents.

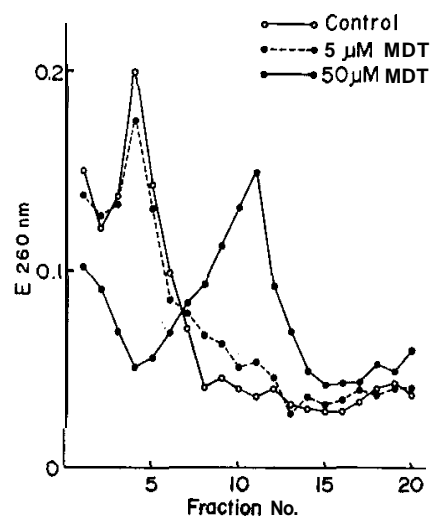

Fig. 3. Neutral sucrose density gradient centrifugation of sarcoma-180 DNA treated with MDT.

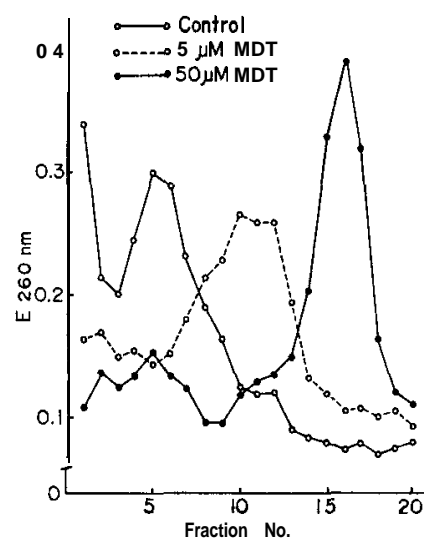

Fig. 4. Alkaline sucrose density gradient centrifugation of sarcoma-180 DNA treated with MDT.

Sarcoma-180 DNA was incubated with 5 or $50 \mu \mathrm{M}$ MDT at $37^{\circ} \mathrm{C}$ for 2 hours and centrifuged. The pattern shown in Fig. 3 indicates that the double strand breakage was caused by $50 \mu \mathrm{M}$ MDT, while not by the lower concentration of $5 \mu \mathrm{M}$. However, the single strand scission by $5 \mu \mathrm{M}$ MDT was detected by alkaline centrifugal analysis, as shown in Fig. 4. It was roughly estimated that the molecular weight was decreased from about $2 \times 10^{8}$ to about $4.9 \times 10^{7}$ in the case of the double strand breakage and that the fragment of about $3.98 \times 10^{6}$ was formed from single strand DNA of about $5 \times 10^{?}$. Thus, it was suggested 
that after treatment of DNA with $50 \mu \mathrm{M}$ MDT about 3 breaks may be formed in the double strand DNA and additional 8 to 9 in one strand.

As shown in Fig. 2, the decrease of the viscosity with MDT was accelerated by $\mathrm{Cu}^{2+}$. Sarcoma-180 DNA was incubated with $5 \mu \mathrm{M}$ MDT in the presence or absence of $5 \mu \mathrm{M} \mathrm{CuSO}_{4}$ at $37^{\circ} \mathrm{C}$ for 4 hours and centrifuged as usual. The results in Figs. 5 and 6 indicate that $\mathrm{Cu}^{2+}$ brought about the enhancement of the depolymerization of both double and single strand DNA with MDT, similar to other nucleic acid breaking reagents.

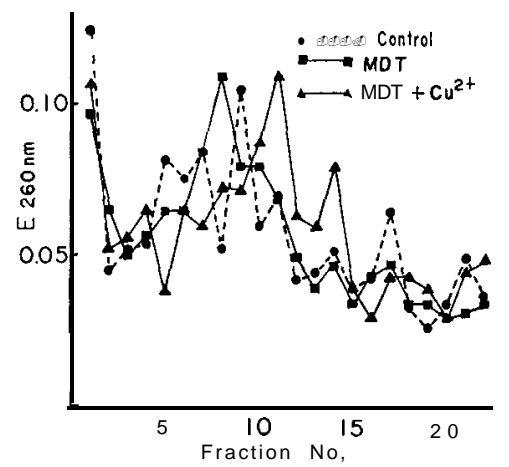

Fig. 5. Neutral sucrose density gradient centrifugation of sarcoma-180 DNA treated with $\mathrm{MDT}+\mathrm{Cu}^{2+}$.

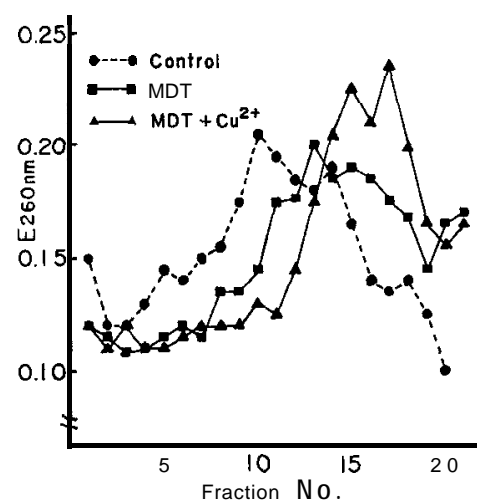

Fig. 6. Alkaline sucrose density gradient centrifugation of sarcoma-180 DNA treated with $\mathrm{MDT}+\mathrm{Cu}^{2+}$.

For comparing the breaking ability of MDT, calf thymus DNA was incubated with MDT of $5 \mu \mathrm{M}, 50 \mu \mathrm{M}$ or $0.5 \mathrm{mM}$ at $37^{\circ} \mathrm{C}$ for 4 hours and the double strand breakage was estimated. From the centrifugal pattern in Fig. 7, it was suggested that the ability of MDT is lower a little than that of triose reductone, but higher than those of amino reductones (Shinohara et al., 1974) or hy. droxyurea (Omura et al., 1973 a). 


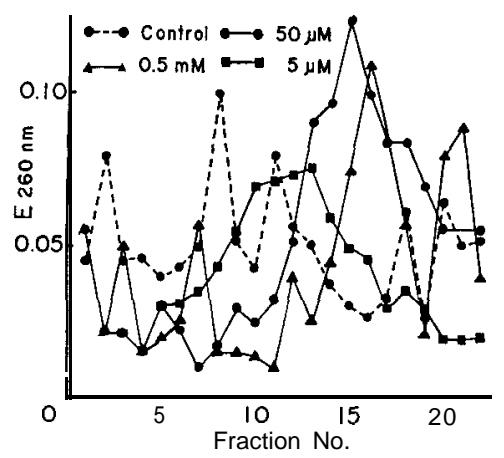

Fig. 7. Neutral sucrose density gradient centrifugation of calf thymus DNA treated with MDT.

\section{Degradation of ApyA and ApuA}

There may be two possibilities for the chemical scission of nucleic acid. One is the scission directly caused by the attack on phosphodiester, and the other the scission induced by the attack on part of base or sugar. Because DNA fragment formed after MDT treatment has still relatively high molecular weight, it is deduced that some specifically susceptible regions may exist in DNA. One of such regions may be consisted of purine or pyrimidine bases arranged successively, purine or pyrimidine cluster. Adrenaline was found to degrade specifically ApuA which has pyrimidine cluster, but not ApyA containing purine cluster (Yamafuji et al., 1970). Likewise, AsA derivatives degrade ApuA, although ApyA is also decomposed to some extent (Nakamura, 1972). In addition, it was observed that pyrimidine tetra- and pentanucleotides were decomposed by DAsA in co-operation with $\mathrm{Cu}^{2+}$, while pyrimidine mono-, di- or trinucleotides as well as all purine oligonucleotides were not (Yamafuji et al., 1971). This suggests that the pyrimidine cluster consisting of more than 4 bases may be specifically attacked by $\mathrm{DAsA}+\mathrm{Cu}^{2+}$.

The reaction mixture containing $500 \mu \mathrm{g} / \mathrm{ml}$ ApyA (or ApuA), $50 \mathrm{mM}$ MDT, $1 \mathrm{mMCu}^{2+}$ and $50 \mathrm{mM}$ phosphate buffer was incubated at $37^{\circ} \mathrm{C}$ for 24 hours and filtered through the column of Sephadex G-50 after dialysis against cold water to remove the low molecular substances. As shown in Fig. 8, it was confirmed that the disintegration of both ApyA and ApuA is similarly caused by the treatment with $\mathrm{MDT}$ and $\mathrm{Cu}^{2+}$.

\section{DISCUSSION}

It was demonstrated by Yamafuji (1970) that one of the initial steps in cytodifferentiation and cytoanomalization such as carcinogenesis, carcinostasis, virogenesis and hormonal action may be ascribed to a suitable scission of chromosomal DNA. In addition to the antitumoric AsA derivatives cited above, the following substances were actually established to depolymerize DNA in vitro and summarized as "nucleic acid breaking reagent ;" namely, carcinogens such as 3- 

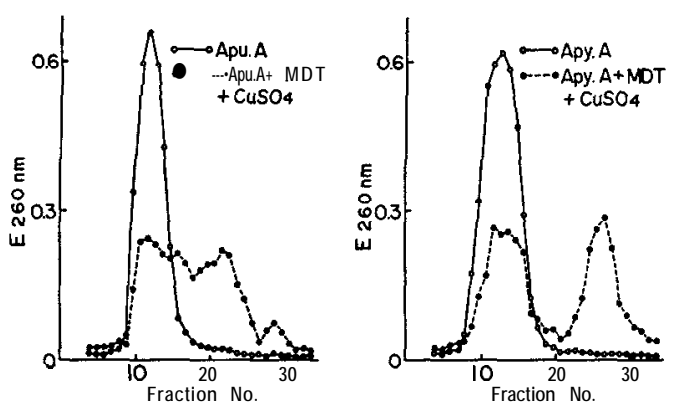

Fig.8. Gel filtration of ApuA and ApyA treated with $\mathrm{MDT}+\mathrm{Cu}^{2+}$.

hydroxyanthranilic acid, 3-hydroxykynurenine (Yamafuji et al., 1972), N-methyl$\mathrm{N}^{\prime}$-nitro-N-nitrosoguanidine and mitomycin $\mathrm{C}$ (Iiyama et al. 1973), virogens and mutagens such as hydroxylamine, nitrous acid and oximes (Omura et al., 1973b), hormones such as cortisone and ecdysone (Yamajuji et al., 1971b). On the other hand, it was presumed that the reductonic nature of catecholamines as well as AsA derivatives attributed to the enediol or its oxidized group takes an essential part in the antitumoric and DNA breaking actions. On the basis of this assumption, both activities were disclosed for MDT in the preceding (Tomita et al., 1974) and present studies. Thus, the work also supports the Yamafuji's hypothesis and MDT was included in the group of the nucleic acid breaking reagent.

As cited above, catecholamines and AsA derivatives decompose specifically ApuA, whereas their action on ApyA is quite weak (Nakamura, 1972). On the contrary, MDT disintegrates ApyA as well as ApuA to the same extent. This seems to indicate that the susceptible region of DNA with the enediol group is not generally coincident among the reductones. The breaking ability of MDT is relatively high. About $50 \mu \mathrm{M}$ MDT caused the double strand breakage accompanied with the decrease of the molecular weight of DNA to about $1 / 4$ and the single strand scission accompanied with the decrease to about 1/11 1/12.

Thus, it seems likely that the reductones possess commonly the property to disintegrate DNA. However, site and number of breaks in DNA may be different with these substances, on which their peculiar specificity may be dependent for carcinogenesis and carcinostasis.

\section{REFERENCES}

Boyland, E. and G. Watson 1956 3-Hydroxyanthranilic acid, a carcinogen produced by endogenous metabolism. Nature, $177: 837-838$

Euler, H. von und H. Hasselquist 1955 Entstehung von aci-Reduktonen. Arkiv Kemi, 8: 6772

Iiyama, S., H. Murakami, M. Kuraki and H. Omura 1973 Action of DNA breaking reagents on RNA, deoxyoligonucleotide and RNA polymerase reaction. J. Agr. Chem.Soc.Japan, $47: 455-461$

Murakami, H. and K. Yamafuji 1969 Antitumor activities of polyphenols. Sci. Bull. Fuc. Agr. Kyushu Univ., 24: 19-24 
Murakami, H. and K. Yamafuji 1970 Mode of action of some catecholamines and sugar oximes on deoxyribonucleic acid. Enzymol., 38: 337-345

Nakamura, Y. 1972 Degradation of deoxyribonucleic acid by dehydroascorbic acid. Res. Bull. Saga Women's Junior College, 6: 1-15

Nakamura, Y. and K. Yamafuji 1968 Antitumor activities of oxidized products of ascorbic acid. Sci. Bull. Fac. Agr. Kyushu Univ., 23: 119-125

Omura, H., Y. Inoue and M. Sato 1973 a Action of hydroxyurea on deoxyribonucleic acid in vitro. J. Agr. Chem. Soc. Japan, 47: 591-597

Omura, H., S. Iiyama, T. Fujii and K. Yamafuji 1973b Effect of virogenic hydroxylaminemetabolites on deoxyribonucleic acid and RNA-polymerase. J. Fac. Agr. Kyushu Univ., $17: 181-186$

Omura, H., Y. Tomita, Y. Nakamura and H. Murakami 1974 Antitumoric potentiality of some ascorbate derivatives. J. Fac. Agr. Kyushu Univ., 18: 181-189

Saito, H. and K. Miura 1963 Preparation of transforming deoxyribonucleic acid by phenol treatment. Biochim. Biophys. Acta, 72: 619-629

Shinohara, K., Y. Fukumoto, Y.-K. Tseng, Y. Inoue and H. Omura 1974 Action of amino reductones on nucleic acids. J. Agr. Chem. Soc. Japan, 48: 499-506

Studier, F. W. 1965 Sedimentation studies of the size and shape of DNA. J. Mol. Biol., 11: $373-390$

Takemura, S. 1959 Hydrazinolysis of nucleic acid I. The formation of deoxyriboapyrimidinic acid from herring sperm deoxyribonucleic acid. Bull. Chem. Soc. Japan, 32: 920-926

Tamm, C., M. E. Hodes and E. Chargaff 1952 The formation of apurinic acid from the deoxyribonucleic acid of calf thymus. J. Biol. Chem., 195 : 49-63

Tomita, Y., M. Eto, M. Iio, H. Murakami and H. Omura 1974 Antitumor potency of 5-methy1-3,4-dihydroxytetrone. Sci. Bull. Fac. Agr. Kyushu U niv., 28: 131-137

Yamafuji, K. 1970 Food. cancer and cytodifferentiation (40th anniversary of Prof. K. Yamafuji's research). Shukosha, Fukuoka, Japan

Yamafuji, K., H. Murakami and M. Shinozuka 1970 Antitumour activity of dopa, dopamine, noradrenalin or adrenalin and their reaction with nucleic acids. Z. Krebsforsch., 73 : 195203

Yamafuji, K., Y. Nakamura, H. Omura, T. Soeda and K. Gyotoku 1971a Antitumor potency of ascorbic, dehydroascorbic or 2,3-diketogulonic acid and their action on deoxyribonucleic acid. Z. Krebsforsch.. 76: 1-7

Yamafuji, K., S. Iiyama and K. Shinohara 1971b Mode of action of steroid hormones on deoxyribonucleic acid. Enzymol., 40 : 2599264

Yamafuji, K., T. Fujii, Y. Kanegae and M. Matsuo 1972 Action of carcinogenic tryptophan metabolites on deoxyribonucleic acid and RNA polymerase. Enzymol., 43: 73-82 